M. Girardin, S. G. OUellet, D. Gauvreau, J. C. Moore, G. Hughes, P. N. Devine, P. D. O'SHEA, L.-C. CAMPEAU* (MERCK FROSST CENTER FOR THERAPEUTIC RESEARCH, KIRKLAND, CANADA AND MERCK RESEARCH LABORATORIES, RAHWAY, USA)

Convergent Kilogram-Scale Synthesis of Dual Orexin Receptor Antagonist

Org. Process Res. Dev. 2013, 17, 61-68.

\title{
Synthesis of MK-6096
}<smiles>COC(=O)C(CCC(C)=O)C(=O)O[Na]</smiles>

$$
\begin{gathered}
\text { D-alanine (3.6 equiv) } \\
\text { glucose ( } 1.45 \text { equiv) } \\
\mathrm{NaHPO}_{4}(0.25 \text { equiv) } \\
\mathrm{NAD}(0.0015 \text { equiv) } \\
\hline \mathrm{PLP}(0.0008 \text { equiv) } \\
\text { lactate dehydrogenase } \\
\text { glucose dehydrogenase } \\
\text { ATA-117 transaminase } \\
\mathrm{H}_{2} \mathrm{O} \text {, r.t., } 42 \mathrm{~h}
\end{gathered}
$$

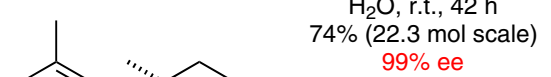<smiles>COC(=O)[C@H]1CC[C@@H](C)NC1=O</smiles>

$$
\begin{gathered}
\underset{\mathrm{NaBH}_{4}(4.0 \text { equiv })}{\mathrm{CaCl}_{2}(2.0 \text { equiv })} \\
\underset{\mathrm{EtOH},<22{ }^{\circ} \mathrm{C}, 20 \mathrm{~h}}{\mathrm{9} \%}(16.4 \text { mol scale })
\end{gathered}
$$<smiles>C[C@H]1CCC(CO)C(=O)N1</smiles>
$\mathrm{dr}=1.2: 1$
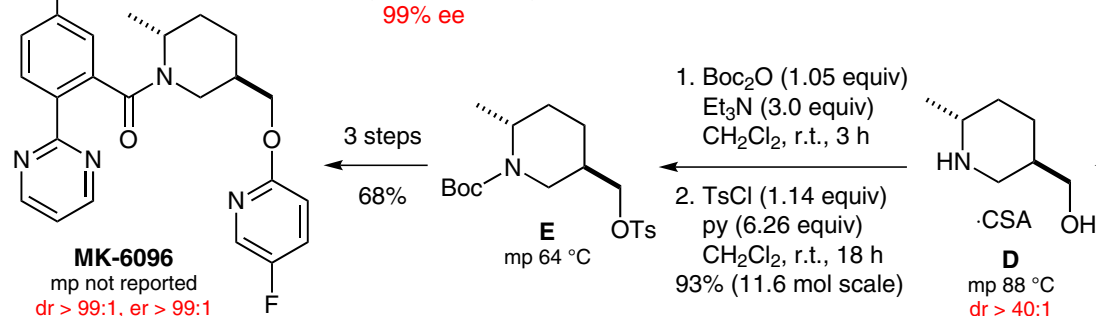

$\mathrm{LiAlH}_{4}$ (4.0 equiv) $\mathrm{THF}, 50^{\circ} \mathrm{C}, 12 \mathrm{~h}$

then $\mathrm{D}-(+)-\mathrm{CSA}$

THF-MTBE

$43 \%$ (14.5 mol scale)

Catalytic cycle for the transamination to piperidone $\mathrm{D}$ :<smiles>COC(=O)C(CCC(C)=O)C(=O)OC</smiles>

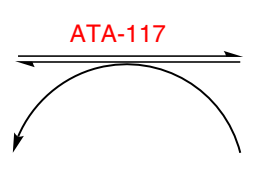<smiles>COC(=O)C(CC[C@H](C)N)C(=O)OC</smiles><smiles>COC(=O)C1CC[C@@H](C)NC1=O</smiles><smiles>C/C(CN)=C(\C)CN</smiles>
$\mathrm{OPO}_{3}{ }^{2-}$

$$
\text { D }
$$

\section{Key words}

\section{MK-6096}

dual orexin receptor antagonist

biocatalytic transamination

\section{SYNFACTenth} of the chang

Significance: The orexins are peptides that act as neurotransmitters in the central nervous system. MK-6096 is a dual orexin receptor antagonist that is a candidate for the treatment of insomnia. A noteworthy feature of the synthesis depicted is the biocatalytic transamination reaction on prochiral substrate A using a three-enzyme cocktail that delivers piperidinone B (>99\% ee) on a multikilogram scale.

SYNFACTS Contributors: Philip Kocienski

Synfacts 2013, 9(4), 0355 Published online: 15.03.2013

DOl: 10.1055/s-0032-1318322; Reg-No.: K01413SF
Comment: The diastereoisomeric ratio of the $\alpha$ hydroxymethyl lactam $(\mathrm{dr}=1.7: 1)$ was improved to $>40: 1$ by reduction of the lactam followed by salt formation using D-(+)-camphorsulfonic acid [D-(+)-CSA]. For the development of transaminase ATA-117 in the manufacture of sitagliptin, see: C. K. Savile et al. Science 2010, 329, 305. 